\title{
BINGKAI PEMBERITAAN REKLAMASI TELUK BENOA, BALI 1- 10 Agustus 2013
}

\author{
Mia Angeline; Lidia Wati Evelina \\ Marketing Communication Department, Faculty of Economic and Communication, BINUS University \\ Jln. K.H. Syahdan No.9, Palmerah, Jakarta Barat 11480 \\ f.angeline@gmail.com lidiaevelina@yahoo.com
}

\begin{abstract}
With the goal of increasing tourism rate, the government plans to reclaim Bali Benoa Bay and Pudut Island to build an integrated tourism area. This plan was rejected by residents fearing the loss of livelihoods and the natural environment is damaged as a result of reclamation, this negative impact was felt when the local government reclaimed the area of Serangan.The purpose of this study was to determine how online media Balipost.co.id and Kompas.com framed the reclamation cases in Bali Benoa Bay. This study used framing analysis, namely by selecting the news published in two online media from August the $1^{\text {st }}$ to $10^{\text {th }}$, 2013. Result of the study was the differences in the framing of the news. Kompas.com tended to be impartial and focused on the elements of "how". While Balipost.co.id had taken a stance rejected the government reclamation plan and focused on the elements of "who" and "why". Suggestion from this study was the government should establish relations with mass media to communicate with the public, especially when there was a new policy involved.
\end{abstract}

Keywords: framing, reclamation, Bali

\begin{abstract}
ABSTRAK
Dengan tujuan meningkatkan pariwisata, pemerintah Bali berencana untuk mereklamasi Teluk Benoa dan Pulau Pudut yang akan dijadikan kawasan marina dan kawasan wisata terpadu. Rencana ini ditolak oleh warga karena takut akan kehilangan mata pencaharian dan lingkungan alam yang rusak sebagai hasil reklamasi, dampak negatif ini sudah dirasakan ketika reklamasi kawasan Serangan. Peristiwa ini menjadi masalah dalam penelitian ini, sehingga tujuan dari penelitian ini adalah mengetahui bagaimana media online Kompas.com dan Balipost.co.id membingkai kasus reklamasi Teluk Benoa di Bali. Penelitian ini menggunakan analisis framing, yaitu dengan memilih berita yang dipublikasikan di dua media online tersebut antara tanggal 1-10 Agustus 2013. Hasil dari penelitian adalah adanya perbedaan pembingkaian berita: Kompas.com cenderung tidak memihak dan fokus pada elemen "how"; sedangkan Balipost.co.id telah mengambil sikap menolak rencana reklamasi pemerintah dan fokus pada elemen "who" dan "why". Saran dari penelitian ini adalah pemerintah seharusnya menjalin relasi dengan media massa untuk berkomunikasi dengan masyarakat, terutama ketika ada kebijakan baru.
\end{abstract}

Kata kunci: framing, reklamasi, Bali 


\section{PENDAHULUAN}

Pariwisata dan turisme telah menjadi subjek penting dalam penelitian budaya. Sekarang ini, budaya tradisional, rumah adat, tari-tarian daerah, dan budaya lokal lainnya dilestarikan dengan tujuan untuk menarik wisatawan dan meningkatkan nilai pariwisata suatu daerah. Dengan tujuan untuk meningkatkan pariwisata, maka Pemerintah Bali sejak 2009 berencana untuk mereklamasi Teluk Benoa dengan membuat pulau baru yang akan dijadikan kawasan marine dan wisata terpadu, serta ditunjang dengan infrastruktur berkelas. Kawasan yang akan direklamasi salah satunya termasuk Pulau Pudut atau Pulau Penyu, dan akan dikembangkan menjadi kawasan wisata, kawasan marine, termasuk sirkuit F1 bertaraf internasional, serta beberapa jasa wisata lainnya.

Pada 2013 ini rencana reklamasi Teluk Benoa kembali muncul dengan membawa nama investor baru yaitu PT Tirta Wahana Bali Internasional. Rencana ini telah dikaji Lembaga Penelitian dan Pengabdian kepada Masyarakat Universitas Udayana (Unud). Terkait dengan rencana reklamasi ini, banyak anggota masyarakat menolak, salah satunya dengan alasan rencana reklamasi bertentangan dengan master plan pembangunan Bali yang tertuang dalam Perda Rencana Tata Ruang Wilayah Provinsi (RTRWP) Bali Nomor Tahun 2009, Perda RTRWP Badung, Perpres Nomor 45/2011 tentang Rencana Tata Ruang Kawasan Perkotaan Sarbagita (Denpasar, Badung, Gianyar, Tabanan), Rencana Induk Pengembangan Pelabuhan Benoa, serta Moratorium Penambahan Kamar Hotel di Bali Selatan (BaliPost, 2013).

Penolakan dari masyarakat makin jelas setelah Gubernur Bali, Mangku Pastika, mengakui telah mengeluarkan SK untuk program reklamasi Teluk Benoa (BaliPost, 2013). Menurut Gubernur Bali reklamasi itu akan mampu menampung 10 juta wisatawan yang akan datang ke Bali lima tahun mendatang, dan akan terbuka lapangan kerja untuk 200.000 orang serta PHR sebanyak Rp 5 miliar per hari dari transaksi di pulau baru tersebut (BaliPost, 2013). Untuk menyuarakan penolakan tersebut, masyarakat lokal menggelar aksi unjuk rasa terutama di kantor Gubernur Bali. Masyarakat takut rencana reklamasi tersebut akan berdampak negatif dengan hilangnya mata pencaharian mereka, dan abrasi serta ombak yang makin besar di kawasan Benoa.

Persepsi wisatawan tidak lepas dari pemberitaan mengenai pariwisata Bali yang ada di media. Media massa mampu menciptakan realitas media (media reality) dan mengubah cara pandang wisatawan yang akan atau telah mengunjungi Bali. Ditambah dengan perkembangan media Internet dengan penyebaran berita yang sangat cepat, sehingga media massa mempunyai kekuatan besar untuk merubah cara pandang dan pola pikir masyarakat. Penulisan dalam media online dapat dikutip dan disebarkan kembali dengan sangat mudah, juga dapat dikomentari secara terbuka oleh para pembacanya.

Sebagian besar media online menjual nilai berita (news value) berupa bad news is good news. Dengan harapan berita yang "terkesan" negatif akan dikomentari oleh banyak pembaca dan menjadikan rating media tersebut meningkat. Karena itu cara membingkai (framing) suatu berita dapat menarik reaksi yang berbeda-beda dari pembacanya. Tema ini dipilih karena kasus ini banyak menarik perhatian masyarakat, khususnya masyarakat Bali, pada bulan Agustus. Pemberitaan yang dipilih adalah dari dua media online yaitu Kompas.com dan Balipost.co.id. Kompas.com sebagai media online nasional banyak menyoroti kasus ini, dibanding media online nasional lainnya yang hampir tidak ada pemberitaan mengenai kasus ini. Sedangkan Balipost.co.id dipilih karena merupakan media online lokal (Bali) yang banyak diakses oleh masyarakat setempat.

Penelitian mengangkat masalah tentang bagaimana media online Kompas.com dan Balipost.co.id membingkai tema reklamasi di Teluk Benoa, Bali. Terkait dengan rumusan masalah, penelitian ini bertujuan mengetahui cara media online khususnya Kompas.com dan Balipost.co.id 
membingkai tema reklamasi di Teluk Benoa di Bali. Sedangkan manfaat penelitian dapat memberikan wawasan, pengetahuan, dan pemahaman cara kedua media online tersebut mem-framing mengenai reklamasi pulau di Bali yang diproduksi oleh media online di Indonesia. Selain itu, penelitian diharapkan dapat menjadi masukan bagi wartawan yang akan menulis berita mengenai pariwisata Bali.

\section{Studi Pustaka}

Dukungan media merupakan kegiatan yang mendukung komunikasi pemasaran yang termasuk di antaranya publisitas. Dari sisi ekonomi, media online meminimalkan biaya promosi. Komunikasi pemasaran di era modern dengan pemanfaat media online merupakan sarana komunikasi yang akan membuka suatu peluang (Machfoedz, 2010).

Komunikasi yang disampaikan melalui media massa online untuk kasus ini dapat juga disebut sebagai komunikasi pembangunan. Ciri dari komunikasi pembangunan ini berkaitan dengan perubahan sosial dan masyarakat menjadi subjek pembangunan seperti yang diungkapkan oleh Deddy Mulyana dalam Dilla (2007).

Di dalam komunikasi pembangunan media massa dapat digunakan sebagai alat untuk menyampaikan informasi. Media massa menurut Goran Hedebroh dalam Dilla (2007:51) dapat dikatakan sebagai pembentuk kesadaran sosial yang dapat membentuk suatu pandangan terhadap masyarakat dan tempat kehidupan mereka. Media dianggap sebagai alat yang dapat memengaruhi, mereduksi pengetahuan, dan menjadi pijakan eksistensi kesadaran sosial yang dapat membentuk wawasan masyarakat mengenai kehidupan mereka.

Publisitas mengenai peristiwa reklamasi Tanjung Benoa yang disampaikan melalui media massa yang dilakukan media Kompas.com dan Balipost.co.id merupakan publisitas bagi Bali. Publisitas merupakan upaya yang dapat dipakai untuk memengaruhi opini publik tentang suatu hal maupun peristiwa (Machfoedz, 2010:21). Penulisan berita yang dilakukan melalui media online salah satu upaya untuk menyampaikan ungkapan mengenai pendapat mereka terhadap reklamasi objek wisata Tanjung Benoa di Bali.

Pesan yang ditulis pada media online tersebut dapat mengubah kesadaran dan dapat menumbuhkan kepentingan-dalam hal ini adalah pandangan wisatawan yang akan berkunjung di Bali. Pesan yang kuat adalah stimulus yang kuat yang berbentuk bahasa maupun visual gerak dan diam yang dapat memotivasi orang untuk mengambil tindakan. Pesan tersebut diharapkan dapat menjelaskan mengenai reklamasi objek wisata Tanjung Benoa di Bali yang dapat memuaskan selera konsumen dan juga dapat menjadi Action to Behavior (mendorong melakukan kunjungan dan mendorong mereka pula untuk melakukannya berulang-ulang (Kennedy, 2008:10-11).

Ciptakan keunikan dengan suatu kreativitas yang tinggi dengan tampilan ilustrasi berupa foto obyek wisata Tanjung Benoa yang secara fisik dapat menarik perhatian wisatawan dari mancanegara maupun wisatawan lokal. Unik artinya berbeda dan menarik perhatian terhadap sesuatu yang ditawarkan. Masyarakat dapat saja tertarik pada visual, tulisan dan janji yang akan diberikan (Kennedy, 2008:21). Hal itu yang seharusnya ditonjolkan dalam pemberitaan tersebut.

Kemudian, pesan yang disampaikan pada pemberitaan tersebut juga haruslah jelas dengan menggunakan strategi SCE (Simple, Clear, dan Economic) dan bertujuan to inform (menginformasikan), to persuade (memengaruhi) dan to motivate (memotivasi/mendorong) yang membantu untuk pemahaman si pembaca media online tersebut (Kennedy, 2008:25). Dapat disimpulkan pemberitaan melalui media online merupakan publisitas yang dapat menjadi sarana untuk komunikasi pemasaran dari obyek wisata Tanjung Benoa di Bali. Tulisan mengenai reklamasi objek wisata Tanjung Benoa, Bali diharapkan dapat meniadi sarana promosi dan disajikan dengan verbal dan 
nonverbal dan disajikan semenarik mungkin sehingga mampu memberikan pandangan yang positif tentang daerah tersebut. Pemberitaan pun harus memenuhi persyaratan sebagai bentuk berita yang simple, clear, dan economic yang dapat mendorong pembaca untuk sampai pada kesimpulan.

\section{METODE}

Penelitian ini adalah penelitian kualitatif dengan metode analisis framing. Menurut Eriyanto (2002:11), analisis framing termasuk dalam paradigma kontruksionis yang diperkenalkan oleh sosiolog, Peter L. Berger. Pendekatan Konstruksionis mempunyai penilaian tersendiri mengenai wartawan, media, dan berita. Fakta atau sebuah peristiwa adalah hasil konstruksi yang bersifat subjektif yang dilakukan oleh wartawan dengan sudut pandang tertentu.

Analisis framing adalah suatu metode yang digunakan untuk menganalisis media. Analisis framing secara sederhana digambarkan sebagai suatu analisis untuk mengetahui realitas (peristiwa, aktor, kelompok, dan apa saja) dibingkai media. Pembingkaian tersebut melalui sebuah proses konstruksi. Realitas sosial dimaknai dan dikonstruksi dengan makna tertentu dan peristiwa dipahami dengan bentukan tertentu (Eriyanto, 2002:3).

Berita-berita yang akan dibahas dalam penelitian ini, menurut Eriyanto dapat dikategorikan sebagai hard news yang didefinisikan sebagai berita yang membahas peristiwa yang terjadi pada suatu saat. Berita ini sangat dibatasi oleh waktu dan aktualitas dan ukuran keberhasilannya dari sudut kecepatan diberitakannya. Peristiwa penolakan masyarakat terhadap keinginan pemerintah untuk mereklamasi Tanjung Benoa merupakan peristiwa yang tidak dapat direncanakan dan masuk dalam kategori hard news (Eriyanto, 2002:109).

Framing adalah suatu proses membuat suatu pesan lebih menonjol, menempatkan informasi lebih daripada yang lain sehingga khalayak lebih tertuju pada pesan tersebut. Menurut Pan Kosicki dalam Eriyanto (2002:252), ada dua konsepsi framing yang saling berkaitan. Pertama, konsepsi psikologi melihat pada proses internal seseorang dan menekankan bagaimana seseorang memproses informasi dalam dirinya. Framing berkaitan dengan struktur dan proses koginitif, bagaimana seseorang mengolah sejumlah informasi dan ditunjukkan dalam skema tertentu. Framing dilihat sebagai penempatan informasi dalam suatu konteks yang unik atau khusus dan menempatkan elemen tertentu dari suatu isu dengan penempatan lebih menonjol dalam kognisi seseorang. Elemen yang diseleksi dari suatu isu/peristiwa tersebut menjadi lebih penting dalam memengaruhi pertimbangan. Elemen yang diseleksi dari suatu isu/peristiwa tersebut menjadi lebih penting dalam memengaruhi pertimbangan.

Kedua, konsepsi sosiologis melihat konstruksi sosial atas realitas. Frame dipahami sebagai proses bagaimana orang mengklasifikasi, mengorganisasikan, dan menafsirkan pengalaman sosial untuk mengerti dirinya dan realitas di luar dirinya. Frame berfungsi membuat suatu realitas menjadi terindentifikasi, dipahami dan dapat dimengerti karena sudah dilabel dengan label tertentu.

Dalam pendekatan ini, framing dibagi menjadi empat struktur menurut Pan \& Kosicki (Eriyanto, 2002:255), yaitu sebagai berikut. Pertama, struktur sintaksis, dapat diamati dari bagan berita yang meliputi cara wartawan menyusun berita. Struktur sintaksis memiliki perangkat: headline yang merupakan berita yang dijadikan topik utama oleh media dan lead (teras berita) merupakan paragraf pembuka dari sebuah berita yang biasanya mengandung kepentingan lebih tinggi. Struktur ini sangat tergantung pada ideologi penulis terhadap peristiwa berupa: latar informasi, kutipan, sumber, pernyataan, dan penutup. Kedua, struktur skript, yaitu cara wartawan mengisahkan fakta dengan melihat bagaimana strategi bercerita yang digunakan wartawan dalam mengemas berita. Struktur ini 
memfokuskan perangkat framing pada kelengkapan berita $5 \mathrm{~W}+1 \mathrm{H}$ yaitu what (apa), when (kapan), who (siapa), where (dimana), why (mengapa) dan how (bagaimana). Ketiga, struktur tematik, yaitu bagaimana seorang wartawan mengungkapkan suatu peristiwa dalam proposisi, kalimat, atau hubungan antarkalimat yang membentuk teks secara keseluruhan. Struktur tematik mempunyai perangkat framing berupa detail, maksud, dan hubungan kalimat, nominalisasi antarkalimat, koherensi, bentuk kalimat dan kata ganti. Keempat, struktur retoris, yaitu bagaimana seorang wartawan menekankan arti tertentu termasuk penggunaan kata, idiom, gambar, dan grafik yang digunakan untuk memberi penekanan arti tertentu. Struktur retoris mempunyai perangkat framing diantaranya pilihan kata yang merupakan penekanan terhadap sesuatu yang penting, grafis, metafora dan pengandaian.

\section{Subjek Penelitian}

Penelitian ini mengambil subjek pemberitaan di kompas.com dan balipost.co.id. Unit observasi adalah pemberitaan terkait rencana pemerintah melakukan reklamasi di Teluk Benoa selama tanggal 1 hingga 10 Agustus 2013. Penelitian ini menggunakan data berupa teks, foto, grafis, dan simbol-simbol yang merepresentasikan orang-orang, tindakan-tindakan dari tema tersebut, dan dimuat dalam berita yang dipilih.

\section{Analisis Data}

Analisis data dalam penelitian ini menggunakan konsep framing yang menekankan pada penonjolan kerangka pemikiran, perspektif, dan konsep media dalam rangka memaknai objek penelitian. Perangkat framing yang digunakan sebagai pendekatan untuk menganalisis data dalam penelitian ini adalah perangkat framing Pan dan Kosicki, yang juga disebut sebagai perangkat wacana, terbagi menjadi empat struktur yang telah dijelaskan. Pendekatan ini dapat digambarkan dalam tabel berikut (Vujnovic, 2007):

Tabel 1 Kerangka Framing Pan dan Kosicki

\begin{tabular}{|c|c|c|}
\hline Struktur & Perangkat Framing & Unit yang Diamati \\
\hline Sintaksi & Skema berita & $\begin{array}{l}\text { Headline, lead, latar informasi, } \\
\text { sumber, pernyataan, penutup }\end{array}$ \\
\hline Skript & Kelengkapan berita & $5 \mathrm{~W}+1 \mathrm{H}$ \\
\hline Tematik & $\begin{array}{ll}\text { 1. } & \text { Detail } \\
\text { 2. } & \text { Maksud kalimat } \\
\text { 3. } & \text { Hubungan antarkalimat } \\
\text { 4. } & \text { Koherensi } \\
\text { 5. } & \text { Bentuk kalimat } \\
\text { 6. } & \text { Kata ganti }\end{array}$ & Paragraf, proporsi \\
\hline Retoris & $\begin{array}{ll}\text { 1. } & \text { Gambar } \\
\text { 2. } & \text { Metafora } \\
\text { 3. } & \text { Pengandaian }\end{array}$ & Kata, idiom, gambar/foto, grafis \\
\hline
\end{tabular}




\section{HASIL DAN PEMBAHASAN}

\section{Analisis Berita Kompas.com Berita 2 Agustus 2013}

Tema berita ini adalah rencana masyarakat Teluk Benoa berencana untuk melakukan demo pada saat KTT APEC yang bertujuan dicabutnya SK Gubernur mengenai pemberian izin investor untuk mengelola Teluk Benoa. Dari analisis sintaksis, latar informasi adalah penolakan warga Teluk Benoa dan mengancam akan unjuk rasa pada saat penyelenggaraan KTT APEC. Hal tersebut terlihat dari lead berikut ini:

Denpasar, Kompas.com - Warga Teluk Benoa, Bali, yang menolak reklamasi Teluk Benoa, mengancam akan menggelar unjuk rasa besar-besaran saat penyelenggaraan KTT APEC di Nusa Dua, Oktober mendatang. (Hasanudin, 2013)

Sedangkan dari segi Skript, berita ini tergolong singkat dan kurang aspek "How" yaitu bagaimana unjuk rasa akan digelar dan bagaimana solusi dari keresahan warga Teluk Benoa. Dalam berita ini dibahas alasan penolakan warga yaitu karena dari segi hukum reklamasi melanggar Perpres mengenai reklamasi tidak dapat dilakukan di wilayah konservasi, serta warga resah karena akan mengancam mata pencaharian warga sebagai nelayan dan penyedia jasa olahraga air.

Dari segi Tematik, berita ini hanya terdiri dari lima paragraf singkat, namun telah disusun secara logis dan tidak memihak. Berita ini juga dilengkapi dengan landasan hukum alasan warga menolak reklamasi Teluk Benoa.

Terakhir, dari segi Retoris, berita ini menggunakan foto Warga Teluk Benoa yang berunjuk rasa di Teluk Benoa dengan membawa berbagai spanduk. Foto ini mempertegas isi berita bahwa ancaman kemungkinan akan dilaksanakan jika tuntutan warga tidak dipenuhi.

\section{Berita 2 Agustus 2013}

Dari lead berita sebagai berikut:

Denpasar, Kompas.com - Ratusan warga Teluk Benoa, Badung, Bali, berunjuk rasa di tengah laut perairan Teluk Benoa, Jumat (2/8/2013), menolak reklamasi seluas 838 hektar di Teluk Benoa. Dengan menggunakan perahu nelayan dan perahu cepat, warga membentangkan berbagai spanduk meminta Gubernur Bali mencabut SK Nomor 2138/02-C/HK/2012 tentang pemberian izin reklamasi Teluk Benoa. (Hasanudin, 2013)

Tema dari lead di atas sesuai analisis Sintaksis adalah banyaknya warga lokal yang menolak rencana reklamasi Teluk Benoa karena akan berdampak buruk pada lingkungan dan kehidupan ekonomi warga.

Dari analisis Skript, berita ini sudah mempunyai elemen $5 \mathrm{~W}+1 \mathrm{H}$, tersusun secara logis sehingga pembaca dapat menangkap pesan berita dengan cepat. Berita ini berisi pendapat atau opini masyarakat lokal mengenai dampak reklamasi pulau bagi mata pencaharian dan lingkungan tempat tinggal mereka. Hal ini dapat dilihat dari kutipan berita sebagai berikut:

"Setelah ada reklamasi kami pasti akan diintimidasi oleh air karena saat ini ketika air pasang Teluk Benoa sudah kemasukan air (rob) 30cm sampai halaman rumah,” ucap I Kadek Duarsa, wakil ketua Himpunan Masyarakat Teluk Bersatu di sela unjuk rasa. (Hasanudin, 2013) 
Sedangkan dari segi Tematik, hubungan antarparagraf sudah logis walaupun berita hanya terdiri dari lima paragraf yang cukup singkat. Isi pesan dari berita ini adalah upaya warga dalam menolak reklamasi pulau yang dilakukan dengan berunjuk rasa diatas perahu dan di daratan di bawah Tol Bali.

Dari segi Retoris, berita ini menggunakan foto warga Teluk Benoa yang sedang berunjuk rasa konvoi dengan kapal laut. Foto ini digunakan untuk mempertegas judul dan isi pesan bahwa tipe unjuk rasa ini termasuk tidak biasa dan upaya yang dilakukan warga beraneka ragam dalam menolak reklamasi pulau yang direncanakan oleh Pemerintah Bali.

\section{Berita 6 Agustus 2013}

Berita ini memuat tema ajakan dari Gubernur Bali untuk melihat potensi jangka panjang reklamasi Teluk Benoa, yang menurut pemerintah dapat membantu warga dan bukan merugikan warga. Analisis Sintaksis, berita ini memuat dialog dan ajakan dari Gubernur Bali kepada masyarakat untuk mendukung rencana reklamasi Teluk Benoa karena dalam lima tahun ke depan akan menguntungkan Bali. Hal tersebut dapat terlihat dari lead sebagai berikut:

Denpasar, Kompas.com - Gubernur Bali Made Mangku Pastika meminta masyarakat melihat prospek reklamasi untuk lima tahun mendatang. Reklamasi pulau bisa menjadi alternatif membuka lahan baru untuk lapangan pekerjaan baru. (Asdhiana, 2013)

Sedangkan dari segi analisis Skript, berita ini sudah lengkap memuat 5W+1H. Dalam beberapa bagian berita terkesan mengajak masyarakat untuk memercayai keputusan pemerintah, dan menghentikan polemik hingga kajian dari Lembaga Penelitian dan Pengabdian kepada Masyarakat (LPPM) Universitas Udayana selesai. Hal ini terlihat dari cuplikan paragraf sebagai berikut:

Reklamasi juga menjadi alternatif untuk menghentikan alih fungsi lahan pertanian. Yakinlah, saya tidak menjual Bali. Justru Bali itu dibuatkan pulau oleh investor. Bali yang mempunyai pulau baru itu," kata Pastika di Denpasar, Bali. (Asdhiana, 2013)

Secara terpisah, Senin, anggota DPRD Bali, Made Arjaya, mengajak masyarakat menghentikan polemik rencana reklamasi Teluk Benoa. Ia meminta masyarakat menunggu hingga kajian selesai. "Jikalau kesimpulan akhirnya reklamasi itu tidak layak, mari kita hentikan bersama. Jika layak, mari kita pikirkan pula bagaimana jalan terbaiknya,” kata Arjaya. (Ashdiana, 2013)

Dari segi Tematik, hubungan antarparagraf sudah logis sehingga pembaca mudah menangkap pesan berita. Isi berita juga banyak menggunakan data dan kutipan wawancara sebagai pendukung kalimat dan memperkuat pesan berita.

Dari segi Retoris, berita ini menggunakan dua foto. Foto yang pertama adalah siswa sekolah dasar yang berlatih menari di sela-sela acara pemberian beasiswa oleh BII. Foto ini memperkuat pandangan pembaca bahwa budaya dan alam bali terkesan "dijual" untuk menarik wisatawan dan secara tersirat kontradiksi dengan pernyataan Gubernur Bali yang tidak menjual Bali. Sedangkan foto kedua adalah seorang warga yang memandang Pulau Pudut, Teluk Benoa. Foto ini digunakan karena Pulau Pudut terancam hilang akibat pengerukan dan abrasi jika tidak direklamasi kembali. Sekarang ini Pulau Pudut digunakan untuk konservasi penyu dan dimanfaatkan sebagai objek wisata oleh masyarakat adat. Foto kedua ini memberikan kesan mendukung pernyataan Gubernur Bali untuk reklamasi Teluk Benoa dan rencana pemerintah akan membawa dampak positif kepada masyarakat salah satunya pada Pulau Pudut. 
Dapat disimpulkan, berita ini menyajikan banyak sisi dari rencana reklamasi Teluk Benoa, satu sisi dari pernyataan Gubernur yang mendukung, di sisi lain dari pernyataan Direktur Eksekutif Conservation International Indonesia, yang mengatakan bahwa reklamasi dapat menimbulkan ombak lebih dari empat meter yang membahayakan. Selain memberikan informasi, berita ini mengajak masyarakat untuk menentukan sikap untuk setuju atau tidak dengan rencana pemerintah.

\section{Analisis Berita Balipost.co.id}

\section{Berita 1 Agustus 2013}

Kutipan lead dari berita ini adalah sebagai berikut:

Denpasar (Bali Post) - Akademisi, LSM, praktisi, sulinggih dan mahasiswa, telah menunjukkan berbagai pelanggaran atas SK Gubernur Bali Mangku Pastika. Namun, Mangku Pastika masih kekeh dengan sikapnya dan tetap tidak mau mencabut SK reklamasi. Alasan Gubernur, bahwa SK tersebut sudah sesuai prosedur dan tidak ada aturan yang dilanggar. Atas sikap Gubernur itu, sejumlah komponen di Bali akhirnya menggelar aksi. (Balipost, 2013)

Dari lead, berdasarkan analisis Sintaksis, latar informasi adalah perbedaan pandangan antara Gubernur dengan masyarakat. Gubernur digambarkan tidak memercayai hasil pelanggaran yang ditunjukkan oleh masyarakat dengan penggunaan kata "kekeh" dalam berita tersebut. Gubernur juga digambarkan "seorang diri" yang tidak memercayai masyarakat yang terdiri dari banyak pihak dan akhirnya karena sikapnya menyebabkan masyarakat berunjuk rasa.

Sedangkan dari segi Skript, berita ini sudah memiliki elemen $5 \mathrm{~W}+1 \mathrm{H}$ dan disusun dengan logis sehingga pesan berita dapat dengan mudah ditangkap oleh pembaca. Berita ini menegaskan elemen "Who" dan "Why". Pada elemen "Who" berita ini menyoroti pihak-pihak yang berunjuk rasa di depan kantor Gubernur Bali, termasuk personel band Superman Is Dead. Sedangkan elemen "Why" ditekankan alasan masyarakat melakukan unjuk rasa, mulai dari landasan hukum, alasan ekonomi yang memprioritaskan investor, dan alasan lingkungan yang akan dirusak dengan reklamasi. Berikut kutipan paragraf terkait:

Puluhan aktivis lingkungan hidup Bali yang terdiri atas Komisi Kerja Advokasi Lingkungan Hidup (Kekal), Walhi Bali, Frontier Bali, BEM Unhil, PPMI DK Bali, Bali Outbond Community serta beberapa musisi dan seniman Bali bersatu menggelar aksi demo di depan kantor Gubernur Bali, Rabu (31/7) kemarin. (BaliPost, 2013)

Tidak hanya aktivis dan mahasiswa yang ikut dalam aksi demo kemarin, personel Superman Is Dead (SID) juga getol melakukan penolakan reklamasi Teluk Benoa. Mereka adalah Jerinx dan Eka. "Saya tidak setuju (reklamasi). Reklamasi itu berdampak buruk bagi ekologi, meskipun dalih ekonomi dan penyelamatan ekologi," kata Jerinx. (BaliPost, 2013)

...menurut Suriadi, SK reklamasi Teluk Benoa yang dikeluarkan Gubernur harus dicabut karena Perpres Sarbagita No. 45 Tahun 2011 Pasal 93 tentang Rencana Tata Ruang Kawasan Perkotaan secara tegas menyatakan bahwa kawasan Teluk Benoa adalah kawasan Konservasi. Selanjutnya dalam pasal Perpres Nomor 122 Tahun 2012 tentang Reklamasi di Wilayah Pesisir dan Pulaupulau Kecil, Pasal 2 ayat (3) reklamasi tidak dapat dilakukan pada kawasan konservasi dan alur laut. (BaliPost, 2013)

Dari segi Tematik, susunan dan hubungan antarparagraf sudah baik dan logis. Paragraf menggunakan berbagai gambaran suasana demo yang dilakukan oleh masyarakat dengan menceritakan detail orasi dan aksi teatrikal yang dilakuakan para aktivis. 
Sedangkan dari segi Retoris, berita ini menggunakan foto situasi demo yang dilakukan oleh masyarakat, dengan orator sedang meneriakkan tuntutan dan spanduk serta bendera dikibarkan di depan kantor Gubernur. Gambar tersebut memperkuat judul dan isi berita mengenai kondisi demo untuk mencabut rencana reklamasi dari Gubernur Bali. Selain itu, tidak ada metafora yang digunakan di isi berita, hanya berisi kutipan yang dari beberapa aktivis.

\title{
Berita 6 Agustus 2013
}

Dalam berita ini, tema yang ditampilkan adalah ketakutan reklamasi Benoa akan berdampak negatif daripada positif. Ketakutan ini beralasan karena dari beberapa reklamasi yang telah dilakukan di Bali, yang menanggung dampak negatifnya adalah masyarakat lokal kelas menengah ke bawah. Lead dari berita ini sebagai berikut:

Mangupura (Bali Post) - Reklamasi Teluk Benoa akan menyebabkan keseimbangan alam berubah. Dampak negatifnya justru lebih banyak ketimbang dampak positifnya. Pemimpin Bali mestinya mempertimbangkan dengan baik keputusan yang diambil, karena hasilnya berkaitan dengan nasib Bali mendatang. (BaliPost, 2013)

Dari analisis Sintaksis, latar informasi adalah kurangnya pertimbangan dari pemerintah Bali untuk belajar dari kejadian reklamasi yang telah dilakukan, dan seharusnya melakukan perkembangan dari segi adat dan budaya karena dua hal itu yang menarik wisatawan, bukan karena fasilitas pariwisatanya yang mewah.

Sedangkan dari segi Skript, berita ini sudah lengkap dengan memiliki elemen 5W+1H. Isi berita ini bertujuan mengajak pembaca untuk menolak rencana reklamasi pulau dengan menggunakan contoh reklamasi di Serangan yang merusak tatanan adat dan agama. Juga dengan memberikan alasan kawasan laut yang disucikan oleh umat Hindu, dan memberikan saran sebaiknya pemerintah Bali mengembangkan eco-wisata yang dikelola oleh desa adat. Berikut kutipan paragraf terkait:

\begin{abstract}
berdasarkan pengalaman sebelumnya, reklamasi besar-besaran tidak menguntungkan masyarakat Bali dan merusak tatanan adat dan agama di masyarakat. "Misalnya reklamasi di Serangan. Itu merusak tatanan adat dan agama. Konsep Tri Hita Karana tidak berjalan, apalagi itu dikelola orang luar Bali," ujarnya. (BaliPost, 2013)
\end{abstract}

Selain itu, ia juga meminta rekomendasi DPRD Bali yang disebut-sebut menjadi acuan bagi Gubernur untuk menerbitkan SK, juga dicabut. "Kalau kami lebih baik dikembangkan eco-wisata yang pengelolaannya oleh desa adat. Tak perlu ada reklamasi. Bisa saja kita kembangkan pasar terapung seperti yang ada di Thailand. Contoh-contoh pengelolaan yang ramah lingkungan itu yang mesti dicontoh. Bukan reklamasi yang jelas-jelas menimbulkan dampak negatif,” kata Sugita. (BaliPost, 2013)

Dari segi Tematik, susunan antarparagraf sudah baik, mudah dibaca. Berita ini juga menggunakan kutipan wawancara untuk memperkuat maksud berita. Terakhir, dari segi Retoris, berita ini tidak banyak menggunakan metafora, hanya menggunakan dalam satu paragraf mengenai kawasan laut yang disucikan oleh umat Hindu dan konsep keseimbangan alam secara Hindu yang tidak bisa dikaji secara akademis. Kutipan paragraf tersebut seperti dibawah ini:

...dikatakannya, kawasan laut sebenarnya disucikan oleh umat Hindu. Kegiatan yang bersifat mengganggu tatanan kesucian alam, jelas berimbas pada manusia itu sendiri. Meskipun nantinya ada kajian akademis yang menghalalkan reklamasi, tetapi tetap saja dari sisi niskala, konsep keseimbangan alam tidak bisa diindahkan. (BaliPost, 2013) 


\section{Berita 10 Agustus 2013}

Dalam berita yang dimuat di situs BaliPost (2013, 10 Agustus), tema yang ada di berita ini adalah pembangunan pulau baru untuk menarik lebih banyak wisatawan ke Bali yang bersifat konsumerisme, sedangkan melupakan inti pariwisata Bali sendiri yaitu kebudayaan lokal. Dari analisis sintaksis, latar informasi adalah rencana pemerintah Bali untuk membangun pulau baru di kawasan Teluk Benoa, padahal seharusnya fokus pemerintah mengembangkan kebudayaan lokal di Bali. Hal tersebut dapat terlihat dari lead sebagai berikut:

Pariwisata Bali tak lagi menjanjikan, tapi menjadi kekhawatiran. Sebab, budaya tak lagi menjadi ikon pariwisata Bali. Budaya tak lagi dijaga untuk mengembangkan pariwisata Bali. Malah sekarang pariwisata mengatur segalanya. Semuanya untuk pariwisata. Bahkan, pulau baru pun akan dibangun demi pariwisata. Seakan-akan pariwisata adalah dewa penyelamat. Seolah-olah masyarakat Bali tak akan hidup kalau wisatawan yang datang ke Bali jumlahnya hanya 3 juta (seperti kondisi saat ini). (BaliPost, 2013)

Sedangkan dari segi Skript, berita ini terbilang sudah lengkap dengan memiliki 5W+1H, pada beberapa bagian dapat merubah pandangan pembaca karena terkesan "menyalahkan” pemerintah Bali karena pembangunan industri pariwisata yang tidak melihat kesiapan Bali. Seperti yang terlihat dalam paragraf berikut ini:

Ini rupanya dikesampingkan oleh pemimpin Bali saat ini. Mereka hanya melihat dari sisi ekonomi bahwa akan datang 10 juta wisatawan, PHR Rp 5 miliar per hari dan menyerap tenaga kerja 200 ribu orang. Mereka tidak melihat daya dukung Bali. Apakah itu menyangkut ketersediaan listrik, air, jalan dan fasilitas hukum lainnya. (BaliPost, 2013)

Inilah yang menjadi kekhawatiran masyarakat Bali. Masuknya dolar, masuknya APBN ke Bali tidak untuk masyarakat Bali. Semuanya untuk memuluskan rencana mereka para investor membangun di Bali bersama-sama dengan para pemimpin yang hanya bermimpi menyejahterakan masyarakat Bali. (BaliPost, 2013)

Dari segi Tematik, susunan antarparagraf sudah baik, disusun secara logis agar pembaca memikirkan arti baru dari pembangunan pariwisata Bali yang telah direncanakan. Berita ini memakai fakta statistik sebagai pendukung kalimat, seperti persentase pertumbuhan penduduk Bali, angka kelahiran, dan jumlah wisatawan.

Dari segi Retoris, berita ini menggunakan beberapa metafora seperti menyebut Pulau Bali dengan "Pulau Surga”, pariwisata Bali sebagai “api”. Penggunaan metafora ini seperti mengisyaratkan pembangunan di Bali tidak semudah yang dibayangkan, tidak dapat hanya fokus di satu bidang saja tanpa ikut membangun yang lain. Hal itu terlihat dari paragraf berikut:

Sebab, Bali yang terkenal keindahan dan keramahtamahannya, kini sudah jauh berubah menjadi keindahan yang banyak direkayasa. Banyak yang mengibaratkan, pariwisata itu seperti "api". Jika diarahkan dengan baik, akan dapat menghasilkan banyak manfaat. Tapi jika tak diarahkan, akan dapat membakar habis. Inilah sebuah kekhawatiran untuk alam Bali. (BaliPost, 2013)

Kesimpulan dari berita ini sebagai kritik untuk pemerintah bahwa pembangunan terus menerus di bidang pariwisata Bali tanpa disertai pembangunan di sisi kebudayaan dan tanpa menyadari implikasinya akan menurunkan kualitas Bali sebagai tujuan wisata yang terkenal didunia.

\section{Perbandingan Representasi Kasus Reklamasi Teluk Benoa}

Pada bagian ini akan dilakukan perbandingan representasi atas kasus reklamasi Teluk Benoa yang dilakukan oleh media Kompas.com dan Balipost.co.id. Analisis bersumber dari pemetaan dengan analisis framing yang telah dijabarkan. Perbandingan tersebut dapat dilihat pada tabel berikut. 
Tabel 2 Daftar Perbandingan Representasi atas Kasus Reklamasi Teluk Benoa

\begin{tabular}{ll}
\hline \multicolumn{1}{c}{ Kompas.com } & \multicolumn{1}{c}{ Balipost.co.id } \\
\hline $\begin{array}{l}\text { Representasi reklamasi imbang, tidak } \\
\text { memihak, disertai alasan yang logis dari } \\
\text { berbagai sisi }\end{array}$ & $\begin{array}{l}\text { Representasi reklamasi adalah negatif dan pasti } \\
\text { membawa dampak negatif }\end{array}$ \\
$\begin{array}{l}\text { Adanya ajakan bagi pembaca untuk menilai } \\
\text { reklamasi Teluk Benoa apakah positif atau } \\
\text { negatif }\end{array}$ & $\begin{array}{l}\text { Adanya ajakan untuk merubah pandangan masyarakat } \\
\text { bahwa reklamasi adalah hal negatif }\end{array}$ \\
Terkait unjuk rasa: fokus pada "How” & Terkait unjuk rasa: fokus pada "who" dan "why” \\
\hline
\end{tabular}

Dari tiga berita yang telah dibahas, Kompas.com memuat isi berita yang imbang dan tidak memihak. Alasan penolakan (atau persetujuan) reklamasi diberikan dari berbagai sisi, baik dari segi hukum, lingkungan, maupun ekonomi dengan gaya tulisan yang tidak memihak Pemerintah Bali maupun masyarakat lokal.

Kompas.com bahkan mengajak pembaca untuk menilai sendiri apakah reklamasi Teluk Benoa merupakan hal yang positif dan pantas diteruskan atau hal negatif yang akan merugikan masyarakat. Hal ini terlihat dari berita yang berjudul "Gubernur: Saya Tidak Menjual Bali” (Asdhiana, 2013) yang mengangkat kasus reklamasi Teluk Benoa ini dari sisi Gubernur. Terkait dengan pemberitaan mengenai unjuk rasa yang dilakukan masyarakat lokal sebagai tanda protes, Kompas.com berfokus pada elemen "how" dengan mengangkat cara-cara unik yang dilakukan masyarakat untuk berunjuk rasa, seperti demo di tengah laut, atau fokus berita pada ancaman demo yang akan dilakukan pada KTT APEC mendatang agar didengar oleh Pemerintah Bali.

Sebaliknya, Balipost.co.id memuat berita yang memihak pada masyarakat dan mengambil sikap menolak reklamasi Teluk Benoa karena hanya akan merugikan masyarakat lokal dan menguntungkan investor saja. Alasan penolakan diberikan dari berbagai sisi, baik dari sisi hukum, ekonomi, maupun lingkungan. Namun terlihat bahwa Balipost.co.id sudah mengambil sikap untuk menolak reklamasi. Isi berita tidak ada yang bersifat ajakan untuk menilai apakah reklamasi positif atau negatif, melainkan ajakan untuk merubah pandangan bahwa reklamasi Teluk Benoa adalah hal yang negatif, karena itu harus dicegah dan jangan sampai dilakukan oleh Pemerintah Bali. Terkait dengan pemberitaan mengenai unjuk rasa, Balipost.co.id berfokus pada elemen "who" dan "why" yang menitikberatkan pada pihak-pihak yang ikut serta dalam unjuk rasa dan alasan mengapa SK Gubernur mengenai reklamasi harus dicabut.

\section{SIMPULAN}

Dari dua media online yang dipilih dalam penelitian ini, keduanya membingkai kasus reklamasi Teluk Benoa dengan berbeda. Media Balipost.co.id telah mengambil sikap untuk menolak reklamasi dan mengajak pembaca juga memiliki pandangan yang sama. Sementara itu, Kompas.com tidak mengambil sikap dan memberitakan secara imbang, serta mengajak pembaca untuk menilai sendiri apakah reklamasi adalah hal yang positif atau negatif. Sebagai media massa online, salah satu ciri utama adalah memberitakan fakta secara objektif dan menyajikan berita apa adanya serta membiarkan masyarakat untuk menilai sendiri mengenai kasus reklamasi ini. Hal ini juga menunjukkan besarnya power media untuk memengaruhi masyarakat. 


\section{Saran}

Dari hasil analisis framing di dalam penelitian ini, dapat disarankan kepada pemerintah untuk menjalin relasi dengan media dan menggunakan media untuk berkomunikasi kepada masyarakat jika ada rencana atau kebijakan baru yang akan diaplikasikan. Hal itu disebabkan, bagaimanapun juga, pembangunan harus bersifat dua arah dan diperlukan dialog antara pemerintah dengan masyarakat agar dapat berhasil. Sebagai tambahan, bagi penelitian berikutnya agar memperluas waktu dan media yang dipilih agar menjadi lebih objektif.

\section{DAFTAR PUSTAKA}

Asdhiana, I. M. (2013, 6 Agustus). Gubernur: Saya Tidak Menjual Bali. Diakses 25 Agustus 2013 dari Kompas:

http://travel.kompas.com/read/2013/08/06/0825362/Gubernur.Saya.Tidak.Menjual.Bali.

BaliPost. (2013, 29 Juni). Jangan Ada Persekongkolan Jual Bali Reklamasi Pulau Baru Harus Ditolak. Diakses 25 Agustus 2013 dari www.balipost.co.id: http://www.balipost.co.id/mediadetail.php?module=detailberita\&kid=10\&id=77321

BaliPost. (2013, 9 Juli). Soal Reklamasi Teluk Benoa Pastika Akui Keluarkan SK. Diakses 25 Agustus 2013 dari Balipost:

http://www.balipost.co.id/mediadetail.php?module=detailberita\&kid=10\&id=77597

BaliPost. (2013, 1 Agustus). Gubernur Mangku Pastika Didemo Desak Cabut SK Izin Reklamasi. Diakses 23 Agustus 2013 dari Balipost:

http://www.balipost.co.id/mediadetail.php?module=detailberita\&kid=10\&id=78362

BaliPost. (2013, 6 Agustus). Reklamasi Akan Rusak Tatanan Adat dan Agama. Diakses 24 Agustus 2013 dari Balipost:

http://www.balipost.co.id/mediadetail.php?module=detailberita\&kid=2\&id=78571

BaliPost. (2013, 10 Agustus). Pariwisata Bali Salah Arah? Diakses 25 Agustus 252013 dari Balipost: http://www.balipost.co.id/mediadetail.php?module=detailrubrik\&kid=3\&id=7782

Dilla, S. (2007). Komunikasi Pembangunan. Pendekatan Terpadu. Bandung: Simbiosa Rekatama Media.

Eriyanto. (2002). Analisis Framing. Yogyakarta: LKiS.

Hasanudin, M. (2013, 2 Agustus). Tolak Reklamasi, Warga Bali Demo di Tengah Laut. Diakses 24 Agustus 2013 dari Kompas:

http://regional.kompas.com/read/2013/08/02/1522169/Tolak.Reklamasi.Warga.Bali.Demo.di. Tengah.Laut\#

Hasanudin, M. (2013, 2 Agustus). Warga Tanjung Benoa Ancam Demo Saat KTT APEC. Diakses 24 Agustus 2013 dari Kompas:

http://regional.kompas.com/read/2013/08/02/1833036/Warga.Tanjung.Benoa.Ancam.Demo.s aat.KTT.APEC 
Iverson, T. J. (2010). Cultural conflict: tourists versus tourists in Bali, Indonesia. International Journal of Culture, Tourism and Hospitality Research, 299-310.

Kennedy, J. E. (2008). Simple, Clear, Economic. Jakarta: Bhuana Imu Populer.

Machfoedz, M.(2010). Komunikasi Pemasaran Modern. Yogyakarta: Cakra Ilmu.

Vujnovic, M. (2007). Framing professionalism and the ethics of journalism and public relations in the new media environment: the case of Armstrong Williams. Journal of New Communications Research, 73. 